

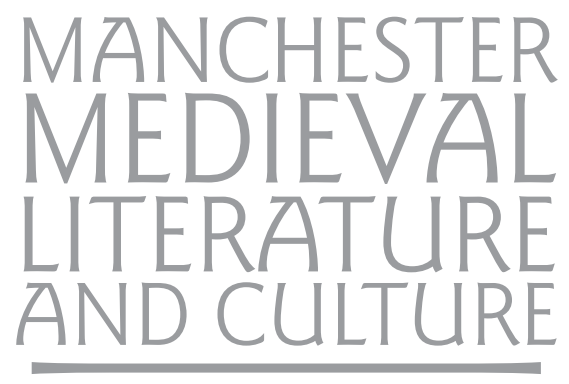

BETWEEN EARTH

AND HEAVEN

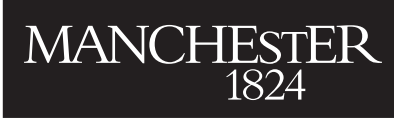

Manchester University Press 


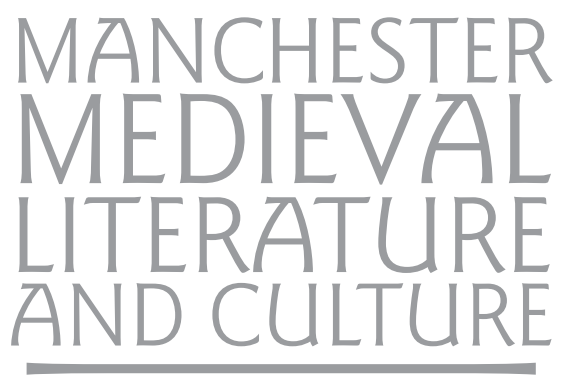

Series editors: Anke Bernau and David Matthews

Series founded by: J. J. Anderson and Gail Ashton

Advisory board: Ruth Evans, Nicola McDonald, Andrew James Johnston, Larry Scanlon and Stephanie Trigg

The Manchester Medieval Literature and Culture series publishes new research, informed by current critical methodologies, on the literary cultures of medieval Britain (including Anglo-Norman, Anglo-Latin and Celtic writings), including post-medieval engagements with and representations of the Middle Ages (medievalism). 'Literature' is viewed in a broad and inclusive sense, embracing imaginative, historical, political, scientific, dramatic and religious writings. The series offers monographs and essay collections, as well as editions and translations of texts.

\section{Titles Available in the Series}

Language and imagination in the Gawain-poems

J. J. Anderson

Water and fire: The myth of the Flood in Anglo-Saxon England

Daniel Anlezark

Rethinking the South English legendaries

Heather Blurton and Jocelyn Wogan-Browne (eds)

The Parlement of Foulys (by Geoffrey Chaucer)

D. S. Brewer (ed.)

In strange countries: Middle English literature and its afterlife:

Essays in Memory of J. J. Anderson

David Matthews (ed.)

A Knight's Legacy: Mandeville and Mandevillian Lore in early modern England Ladan Niayesh (ed.)

Greenery: Ecocritical readings of late medieval English literature Gillian Rudd 


\section{Between earth and heaven}

Liminality and the Ascension of Christ in Anglo-Saxon literature

JOHANNA KRAMER

Manchester University Press

MANCHESTER AND NEW YORK

distributed in the United States exclusively by Palgrave Macmillan 


\section{Copyright (C) Johanna Kramer 2014}

The right of Johanna Kramer to be identified as the author of this work has been asserted by her in accordance with the Copyright, Designs and Patents Act 1988.

Published by Manchester University Press

Oxford Road, Manchester M13 9NR, UK

and Room 400, 175 Fifth Avenue, New York, NY 10010, USA

www.manchesteruniversitypress.co.uk

Distributed the United States exclusively by

Palgrave Macmillan, 175 Fifth Avenue, New York, NY 10010, USA

Distributed in Canada exclusively by

UBC Press, University of British Columbia, 2029 West Mall,

Vancouver, BC, Canada V6T 1Z2

British Library Cataloguing-in-Publication Data

A catalogue record for this book is available from the British Library

Library of Congress Cataloging-in-Publication Data applied for

ISBN 9780719087899 hardback

First published 2014

The publisher has no responsibility for the persistence or accuracy of URLs for any external or third-party internet websites referred to in this book, and does not guarantee that any content on such websites is, or will remain, accurate or appropriate.

Typeset in 10/12 Imprint MT by

Servis Filmsetting Ltd, Stockport, Cheshire 